Western University

Scholarship@Western

$11-28-2019$

How do you solve a problem like the whole user? The construction of worthy and problematic users in online discussions of the public library

Pam McKenzie

University of Western Ontario, pmckenzi@uwo.ca

Follow this and additional works at: https://ir.lib.uwo.ca/fimspub

Part of the Library and Information Science Commons

Citation of this paper:

McKenzie, Pam, "How do you solve a problem like the whole user? The construction of worthy and problematic users in online discussions of the public library" (2019). FIMS Publications. 269.

https://ir.lib.uwo.ca/fimspub/269 


\title{
How do you solve a problem like the whole user? The construction of worthy and problematic users in online discussions of the public library
}

\author{
In this article I use a discursive approach and the concept of the "category \\ entitlement' to analyse the ways that contributors to a public Internet discussion \\ of the value of the public library make cases for different user characteristics and \\ behaviour as 'worthy' or 'problematic', and use these characteristics to discuss \\ and debate the kinds of individuals and the kinds of behaviour that properly \\ belong to each category. Contributors to the discussion represented users in three \\ categories: a fluid 'everyone', which included people represented as being \\ disadvantaged and in legitimate need of the library's resources, expertise, and \\ support; the user in-formation, whose worthy variant takes advantage of the \\ library's offerings to achieve success in economic, cultural, and civic domains \\ and whose problematic variant fails to do so; and the visceral user who may meet \\ bodily needs or engage in pleasurable non-purposive activities and who is \\ deemed worthy or problematic based on their behaviour in the library space. \\ Despite public libraries' growing emphasis on serving the whole user, these \\ public comments prioritise users who exercise their mind to develop into worthy \\ members of a community and who meet behavioural expectations consistent with \\ quiet intellectual activity.
}

Keywords: public libraries; users; problem patrons; discourse analysis; category entitlement

Word count: 7795

\section{Introduction}

Public library staff have long been concerned with how to handle users who pose problems for them and for other users. The professional library literature contains several typologies of 'problem’ users or patrons (e.g., Shuman, 1989; Blessinger, 2002, Chattoo, 2002, Redfern, 2002). What makes users a 'problem' is typically expressed in terms of demographic categories (e.g., 'the problem of homeless patrons,' Blessinger, 2002) or particular forms of behaviour (e.g., Blessinger, 2002; Sheih, 2016). 
The construction of some categories of users, or some classes of user behaviour, as 'problems' is not new. However, what counts as problematic varies over time and across contexts (Ferrell, 2010), and is neither uniform nor uncontested. For example, 19th century British public libraries sought to inculcate respectable values and habits in users such as punctuality, hard work, thrift, and self-control (Black, 2005). Female and juvenile users were viewed with particular unease (Peatling, 2002). In the 19th century USA, unemployed young men were seen to need moral and socially improving materials to counter the delinquency of the saloon and the street corner (Stauffer, 2016).

Attending to the representation of library users lets us see how some kinds of users and behaviours are described and understood as benign or problematic, with implications for public library users, staff, and services. In this article, I report a discourse analysis of the representation of worthy and problematic users in statements made on the public web in response to a Forbes post (Mourdoukoutas 2018a, b) that advocated for the replacement of public libraries with Amazon outlets.

In particular, I take up the concept of the 'category entitlement' (Potter, 1997) to analyse how the categories of worthy and problematic library user are constructed and contested. In an era when public libraries in many countries are moving toward serving the 'whole user' (Latham \& Lenstra, 2018), it is useful to consider the ways that commenters, both supporters and critics of public libraries, represent the user, and the extent to which representations of unproblematic or worthy users and uses reflect the whole person (emotional, occupational, physical, social, intellectual and spiritual).

\section{Literature review}

Several Library and Information Science (LIS) scholars have taken a discursive approach to analysing the representations of library users in LIS research and 
professional literature, library policy documents, and in library workers' communications. Nardini (2001) found that metaphors in the American library literature between 1876 and 1926 developed through a remote storehouse with a legitimately reluctant user; a school and a church with users as students and prospective believers; industrial metaphors of workshops, laboratories, quarries, with labouring users; to offices and machines with users as customers or cogs. Nardini argues that, beyond simply functioning as means for describing the library and its work, 'Metaphor became a way to disagree about libraries' (p. 131). Barniskis (2016) showed that 21st century American public library mission statements use business metaphors and terms like 'business-like' and 'respectful,' which privilege quiet transactions that enforce particular social norms.

Foucauldian approaches show how institutionally privileged speakers' statements construct the identities of users in ways that enable the operation and relations of institutional power. The 'user-centred discourse' in LIS research has been critiqued for representing users simultaneously as self-directed individual consumers -to the neglect of broader social and cultural factors (Frohmann, 1994; Olsson, 2005, 2009/2016, 2016, Willett, 2016), and as deficient or needy; dependent on the intervention of the expert librarian counsellor who can diagnose users' hidden mental states, propose treatments (Tuominen 1997), and relieve suffering (Haider and Bawden 2007).

Ross $(1987,2009)$ showed that metaphors dating back to the late-19th-century library literature support particular representations of readers and their worthiness as library users. The 'reader with a purpose' uses leisure time productively to make steady progress up the reading ladder, in contrast to the unworthy pleasure reader who is lazy and easily distracted. The child reader needs firm guidance away from mediocre works 
toward 'only the best' books. The 'reader as dupe' is helplessly inundated by a deluge of substandard popular culture commodities. Other models represent the reader as an active meaning-maker, but Ross argues that these metaphors of the passive reader acted on by texts continue to pervade the professional literature and to shape reader's advisory services.

Social constructions of children as library users are particularly telling because they suggest representations of children as future adults and society members, and hence give an idea of what future society ought to be and what the library's role is in achieving it. McDowell $(2011,2014)$ shows that late 19th and early 20th century librarians used the metaphor of the reading ladder to represent children as expanding their knowledge, conforming to middle-class American expectations, and being transformed into better citizens through library use and librarian assistance. Behaviour and discipline were topics of significant discussion and debate. Stauffer (2014) found that the popular American construction of children in the nineteenth-century reflected concerns around children becoming delinquents and therefore a danger to society. Home and library were constructed as sites where children could be prepared for adulthood by being taught socially-acceptable moral values and cautioned of the consequences of transgression. A century later, children were framed as vulnerable and in danger from society; home and library were seen as safe spaces where children could be protected from the realities of adulthood. Stauffer argues that librarians' views of childhood as a time to learn about and prepare for adulthood increasingly came into conflict with shifting societal and legal view of children as needing protection from sensational and controversial materials. LIS scholarship continues to be dominated by a developmental approach that represents children as needing training, education, and appropriate information systems, all of which must be provided by adult experts 
(Rothbauer and Gooden 2006, Lundh, 2016). This framing creates a position of power for adults and a position of need for children.

Discourses of delinquency shape representations of young adults as a 'problem' class of users (Chelton 2001, 2002). Bernier (2011) found that news media representations of youth as troubled, troubling, and dangerous may shape libraries' responses to actual youth behaviours and lead them to overlook the civic roles youth play in communities. Given (2003) found that university and academic library policies similarly positioned 'traditional' (18-24 year old) students as immature and not sufficiently serious.

A common representation positions the public library as benefiting the community as a whole, contributing to democracy and the development and maintenance of a 'free society' (Barniskis 2016) or 'the public' (Newman 2007). Hedemark, Hedman, \& Sundin (2005) found that Swedish public library journals designate users as an overarching target group (e.g., the public, everybody), reflecting a politically correct idea of the public library as a forum for general education in a democratic society. However more complex and problematic forms of reasoning underlie the construction of the 'everybody' that the public libraries are meant to serve. Youth is framed as important but troublesome, children are linked with protection, learning, supervision, and guidance, and 'neglected groups' is a heterogeneous category, whose common characteristic is a victim status. These representations are framed within four broad discourses. The general education discourse frames the user as someone in need of education. It distinguishes between high and low culture and therefore presents the public library as superior to common taste: holding quality literature over lesser entertainment materials. The pedagogical discourse defines the user as being unaware of their own unconscious information needs, which only the 
librarian can diagnose. The information technology discourse speaks of a user as 'customer,' an individual with the right to demand library services but also in need of guidance. The information management discourse reflects market-economy thinking and conceptualises users as customers or clients; the role of libraries is to offer what users want. Although this discourse may appear to represent the user as capable, it takes for granted that users are 'strong-willed, unafraid and focused,' and de-emphasises the social responsibility implicit in the general education discourse.

Talja (2001) identified three interpretative repertoires, 'relatively internally consistent, bounded language units' (Wetherell \& Potter, 1988 p.171), at play in interviews with music library users. The general education repertoire privileges the library as a site for education and the music collection as a repository of 'high' elite or mainstream music. Users are identified as music students or entertainment listeners and the library fosters, refines, and controls access to traditional musical taste. The alternative repertoire privileges the library as a place of social inclusion and therefore privileges a collection that reflects a diversity of musical forms and origins for a diverse user population. The demand repertoire sees the collection as properly following local demand and users as passive listeners or specialized fans (pp.64-65).

The scholarship shows that different constructions of users have developed over time and have shaped libraries' treatment of users. In this article, I build on this literature in two ways. First, research to date has been limited to studying what library workers or LIS scholars have said about the user. I analyse how 'the user' is constructed in a public Internet discussion of the value (or not) of the public library. Second, rather than analysing representations of library users meeting particular demographic criteria, like children, or engaging in particular kinds of uses, like reading, I use the concept of the 'category entitlement' (Potter, 1996) to analyse the ways that 
contributors to this discussion make cases for different user characteristics and behaviour as 'worthy' or 'problematic,' and use these characteristics to discuss and debate the kinds of individuals and the kinds of behaviour that properly belong to each category.

\section{Methodology}

On July 21 2018, an American economics professor posted and tweeted out an opinion piece on a Forbes blog (Mourdoukoutas 2018a) arguing for the replacement of local libraries with Amazon outlets. On July 23, after a robust Twitter critique, the author posted a revised edition (Mourdoukoutas 2018b). By July 26, the article URL produced a 404 error and a disclaimer from Forbes, and only archived versions of the original and revised article were available. Between July 21 and 28, the author's two tweets and the article in its original and revised versions occasioned numerous spontaneous, spirited, and broad responses on the public Web debating and defending the value of the public library. These responses included statements about and descriptions of the kinds of users appropriately served by public library, and the appropriate and inappropriate uses that users might make of the institution.

To develop a corpus of these statements, I conducted two Google searches, one on 26 July and one 28 July, to capture responses in the week following the posting of the initial article. I also followed related public links that appeared on my personal Facebook feed between July 21 and 28 2018. I saved a local copy of all of the Google results pages and checked every URL, removing false hits, and saved local html, pdf, and/or Word captures of all potential corpus items. I went through all saved items and eliminated duplicates, (e.g., I only included a single instance of syndicated or reblogged articles but noted all URLs). I limited the corpus to text and image files, for example 
eliminating video news items. The resultant corpus comprises 142 unique Englishlanguage items (See Appendix 1) that a) were freely available on the open Web (e.g., excluding articles behind paywalls); b) were published or posted between July 21 and 28 2018; c) specifically mentioned the Forbes post (e.g., Seebruch, 2018 was excluded from the corpus); and d) appeared in the results of my searches. The corpus includes Twitter and discussion forum conversations; blog posts; local, regional, national, and international news stories and editorials; and posts on content aggregator sites. The original posts and tweets referenced 'community' libraries. Most responses explicitly or implicitly referenced free public libraries, but others discussed academic libraries.

The corpus includes both short (e.g., individual tweets, summary posts linking to larger items), and long items (e.g., long-form journalism and blog posts, strings of Twitter responses, long discussion forum posts). Some items were authored by a single individual, while others included hundreds of comments reflecting varied points of view. Items originated from a variety of countries including the U.S.A., Australia, Great Britain, Ireland, and Canada. Authors included library staff, people in the book trade, journalism, technology, business, and the arts, library users and non-users, and many anonymous and pseudonymous posters who provided opinions with little or no autobiographical information. Mourdoukoutas' two tweets received over 15000 replies; I captured only the direct responses, expanding all of the first-level conversations publicly available to non-followers. The corpus is therefore comprehensive but not exhaustive, and represents a unique and by no means universal set of representations of library users.

I entered all items into NVivo 12. I undertook data analysis in three stages. First, I conducted a content analysis to identify instances of statements about the library and its users. This allowed me to exclude, for example, discussion of Forbes' economic 
model and editorial policies, the author's credentials, motivations, and the quality of his arguments. I coded a total of 2068 instances ranging from less than one line to full pages. Not all instances are unique; for example, many items reproduced a series of tweets, and several popular tweets were replicated across multiple items. In addition, many items quoted others directly. Coding for instances allowed me to take an initial pass through the full data set to understand what it contained. Second, I coded all instances broadly for content facets (e.g., users, resources, services). For this article I describe the analysis of the 1355 instances across 122 items that directly or indirectly mentioned users; for example, I considered mentions of library programs or services as implicitly referring to their actual or potential users.

As I coded for users, I noted that authors made explicit and implicit judgements about the worthiness of different kinds of users and uses. The third stage was to analyse those judgements to identify the category entitlements of worthy and problematic users. Jayyussi $(1984,73)$ identified five types of criteria that people use in defining the 'category incumbency' for particular groups: perceptual availability (what group members look like); behavioural availability (how group members tend to act); personal avowals (claims to belong to a particular group); third person declarations (what people say about them); and formal credentials. Two exemplars of previous research show how category entitlement has been analysed. Potter $(1996,136)$ observed that the criteria newspaper reporters used to distinguish 'community leaders' from other community members in stories were 'diffuse' and 'particularly complex'. The category ‘community leader' was not established by personal credentials or claims (e.g., 'I am a community leader'), but membership in the category 'community leader' depended on what a person did and how they were perceived by other community members, was temporary rather than permanent, and was earned in complex ways. McKenzie and 
Stooke (2001) analysed how the professional literature for teachers and librarians represents the category entitlements of 'literacy experts.' They found that writers for both audiences framed librarians' entitlement around literacy expertise about children's materials, teachers' with reference to their pedagogical knowledge, and parents' from their everyday access to and knowledge about their own children. The literature therefore carved literacy expertise into three discrete domains, over which each group claims primary expertise; children themselves were not accorded any expertise. The value of each domain was contested, with the result that representations of librarians' and teachers' professional expertise may devalue the work of parents and children, and each profession's specification of an exclusive domain of expertise can support the construction of barriers to meaningful collaboration among librarians, teachers, and parents.

For this study, I analysed the representations of users for the ways authors described, contested, and defended the criteria for membership in the categories of worthy and problematic user. In reporting my findings, I seek to present the breadth of category claims rather than providing an accounting of frequencies. I also present individual representations not as the perspectives of their authors but rather as indicative of broader discourses circulating in the developed English-speaking 21st century world.

\section{Findings}

In describing the library's responsibility to serve users, many posts focused the broader collective, framing this in terms of community,

Libraries are vital! You cannot have a healthy community without one. [80]

A library is a flagship for a community, a reason people from other communities come to not only visit the library but spend money in that city. [6] 
Libraries with trained staff are worth any tax required; even nonusers profit from their community's quality of life. [58]

An important function of libraries is to adapt to its community's needs. They fill gaps of other agencies \& prepare for future needs when those issues are remedied. [11]

society,

The role of libraries is to equip the whole of society with the skills, information, connections, and services they need to flourish. $[67,126]$

or civilisation

Public libraries are this thing called the common good - we all share in paying for them so that others with less means benefit. It's what humanity does to advance civilization. [58]

As Hedemark et al (2005) found, words like 'everyone' stood in for a general commitment to the collective.

We welcome everyone - no matter your age, gender, background, incomewhether you come in a three-day old beard or three-piece suit. No Visa, membership, or fee is required when you walk through our doors [24];

[Libraries are] spaces of absolute equality, where anyone can come, regardless of financial resources, to study, learn, and hang out. You don't have to purchase anything in order to get to sit in them, you don't have to be means-tested or background-checked. They give the same things to everybody, and there's something beautiful (and increasingly rare) about that. Privatization generally involves the elimination of that kind of place [45];

This effort echoes a sentiment I found etched across numerous other library systems - one of radical inclusion and desire to serve as many members of the community as possible. [63] 
When authors listed categories of people to explain what 'everyone' included, they highlighted what Hedemark et al (2005) termed neglected groups.

We deal with everyone, that means everyone, including victims of violence, the homeless, the mentally ill, predators, etc. [29]

Did you know that public \#libraries serve *everyone*, including *gasp* THE POOR? [11].

Beyond these general representations, authors discussed two more focussed categories of users, each of which comprises worthy and problematic variants. The first is the user in-formation, whose worthy self uses the library to improve their life and circumstances. The problematic user in-formation fails to take advantage of the opportunities the library provides. The second is the visceral user, who is deemed worthy or problematic based on their behaviour in the library space.

\section{The user in-formation}

Descriptions of the user in-formation are rooted in developmental metaphors and use the language of learning, progress, and betterment. 'Everyone' can use the library to help them improve their lives; members of neglected groups in particular demonstrate the promise that the library can support them in escaping their station and lot in life.

There's also a population of homeless people who really do use the libraries' resources to look for help like job search, shelter, rehab, to communicate with loved ones, get away from actual street life. [133]

Libraries are institutions of conscious equity. They ensure that the underprivileged, the unemployed, and the ignored have a place to go, and access to the resources necessary to improve their lives; from a glass of water and a bathroom, to access learning materials and job applications, to a place to study for an exam or finish an important report. [83] 
Bookstores [are not equal to] libraries, they just aren't the same thing and to propose this idea is to take away free information from those who don't have a home life that fosters learning and progress. [57]

The issue is who has access to books, literacy, and life-enriching programs. It can't just be the people who can afford an Amazon Prime subscription. [74]

Posts contained three variations on the user in-formation that showed how a worthy and appropriately purposeful and self-directed -- user could take advantage of the library's resources, services, staff, and facilities for self-improvement. Users who failed to appreciate or take advantage of what the library offered were characterised as problematic.

The first variation, the 'library-made user,' presents the library as a place where users can develop and progress, and success is measured in economic and class terms.

you do know that an educated public can make your country more money right? There's a reason people have to learn how to read. [59]

As an economist, you'd think [the author would] understand the concept of economic mobility - the ability to move from a lower economic status to a higher one - and that libraries provide free access to experiences and information that helps equalize access to opportunities to change one's own economic status in a city. [57]

As was the case in 19th century US and UK, the public library with its salutary materials and services is framed a place where a user can not only learn and climb the reading ladder (Ross 1987) out of poverty and into self-improvement, but also avoid falling into delinquency:

Yeah, close libraries and see a spike in teen pregnancy rates, drug use, and petty crime.... [55] 
There is a lot of information out there which clearly demonstrates that the strongest and healthiest communities out there are those that invest in public education and public libraries and the arts and in helping to bring the poor up and out of poverty. Literacy rates, for example, are tied into crime rates. Third grade reading proficiency is actually a pretty good indicator of what future crime rates for a city might look like. [27]

The library-made user may learn through formal education or be a self-motivated autodidact.

Back in the 1800's the public library was a place of knowledge and wonder. All you needed was a library card (or whatever other means they used back then) and you had access to more books than some of the richest people in the country. Books were expensive and if you could read, the library was the start of self education that could lead you to a prosperous life.... [57]

Reading is an important activity for the user in-formation, particularly the child.

Children become readers, readers become learners, learners become workers, as several first-person accounts and accounts of famous people attest:

Yes, mothers (and fathers, and grandparents, etc.) should read aloud to children at home. But what home has all the storybooks that could feed a growing child's mind? Also, storytelling sessions at a local library are good excursions for both the child and the person taking the child to the storytelling session, good for them to 'get out of the house', good for them to be interacting with others, good for them to experience other ways of telling stories (not all story telling sessions are just reading aloud from books), and good to BE in the community. /s/ Not a public librarian, but an academic one who can see the results of such activities 15-20+ years down the road. [71]

It is safe to say that the public library had a lot to do with my success in school and in the workplace. [123] 
Abraham Lincoln educated himself at a library. So did Malcolm X. Scientists, historians, researchers of all types depend on libraries. Compared to the funding that libraries receive, the payoff they provide is huge. You can't know which kid will go on to change the world. /end [32]

The library provides this dream for all, but particular groups of users are identified as having specific needs to be met by targeted services. Everyone needs to know how to read, immigrants need to learn how to speak English, the unemployed need assistance in gaining employment, people over 40 need to learn technology:

Libraries also provide a stop-gap for where other social services end. We teach people how to read. We help boomers and early Gen X'ers learn new technologies and digital skills. We teach ESL and train for citizenship exams. We write resumes and cover letters. [11]

The unworthy user in-formation fails to take advantage of the library's many opportunities for self-improvement,

I'm sure you can find plenty of illiterates at the library, but they're not there for the books. [95]

and risks not being financially successful and therefore not pulling their weight in contributing to the community.

If there's a problem with modern public libraries it's that many of the people who use them aren't the ones who pay for them.... Studies done by my local library have found it's being used by homeless, unemployed, and other people in similar situations. These are people who are not likely to be paying a property tax or even much of the city sales taxes. [101]

Thus, the user in-formation's willingness and ability to engage in self-education and self-improvement becomes the threshold between maintaining worthy user status and slipping into the problem user category. This discussion summarizes the slippery slope 
from promising neglected group member to problem user:

Commenter 1: After everything else, if you are poor af you can go to the library and get any book you want. They can even ILL [inter-library loan] it from libraries around the country or world. Since this is [a literature forum], I assume this has some value amongst us.

Commenter 2: What makes you think poor people use libraries for self-education or reading? That's a rather absurd claim.

Commenter 3: Libraries have definitely lost their way. They no longer prioritize book curation and research assistance. They fancy themselves an arm of the social services now.

Commenter 4: In my local city the library is a daycare for homeless people. it is disgusting [59]

The second variant of the user in-formation is cultural. Here, the worthy user succeeds in developing intelligence, discernment, and taste, and the unworthy user is relegated to consuming worthless popular material. We see metaphors of reading at play, and the physical book becomes an important vehicle for conveying cultural knowledge and capital.

It is a part of American Culture to provide a system of public libraries for the improvement of all minds. I am happy to pay my share of taxes, as libraries are an essential part of the fabric of our society. [95]

In more than one source, R.L. Stein's Goosebumps series stands in both for the kind of culturally valueless material libraries and aspiring users in-formation should avoid,

Commenter 1: [Libraries] should be replaced by book drops and Amazon. Libraries are what's wrong if they had you reading Goosebumps. [59]

and for the hook that brings the child reader into the library where their tastes are educated as they are exposed to quality material. 
Commenter 4: Libraries are the only good thing about this horrible country.

Nothing beats my memories of borrowing R.L. Stein books and puppets when I was a poor little kid. I don't want to raise my children in a country that throws kids to the curb so that their natural drive to learn is milked by corporate shit heads who just want a quick buck. Libraries are a testament to humanity's greatest potential. To be able to archive all of human knowledge, art, and achievement bundled with public classes, help for the downtrodden, bettering the lives of children, and providing a local space - free from profit - for communities to organize and show their own art and achievement. [59]

Finally, the user in-formation may take advantage of the library's resources to become an active and discerning citizen, engaging fully in democratic life with free access to information and sufficient information literacy to reject liberal or conservative (depending on the inclinations of the writer) misinformation. The user who fails in this task becomes a political dupe, at the mercy of the elites who would control their access to information and trick them into acquiescence with their political agenda.

'Whatever the cost of our libraries, the price is cheap compared to that of an ignorant nation.' - Walter Cronkite [85]

Libraries, along with public education, are among the last stalwarts of the democracy this nation envisioned. I also view libraries as defenders of the most important freedom of all, free access to information. [3]

Historically those with power overtly protected their position by keeping oppressed communities illiterate. This idea is a modern reincarnation. Libraries serve POC [people of colour], the poor, etc. They are where people apply for citizenship, register to vote, access social programs. [5]

I have lived in my current house, a block from my local library, for 20 years. I've only ever been there to vote, because it's my polling place. I happily pay taxes to keep it, and the public schools for the children I'll never have open, because I prefer not to live surrounded by people who are stupid. [29] 


\section{The visceral user}

Descriptions of the visceral user focussed on the physicality of the user's interaction with the library, its spaces, staff, resources, and programmes, and include the emotional dimensions of this physical experience. Evaluation of users' worthiness hinges on the behaviour of their physical bodies.

The visceral user may experience the library as a place of both physical and emotional safety. This representation was a common feature of first-person accounts:

[The library] was the place I hid from my science teacher who demanded I dissect a frog and it's the only place I've ever felt truly at home. [3]

One of my friends in grade school had an abusive \& controlling step-dad. We used to spend hours in our local library because it was one of the only places he'd let her go. [29]

The worthy visceral may use the library to meet bodily needs:

In the library, you're not loitering, you're lingering, and there's a world of difference in how that feels. Also, libraries can serve as cooling centers for people who don't have A/C when the temp exceeds 100F. [100]

Our library provides a space where [neglected groups] can use free computers and wifi, as well as access a climate-controlled environment with clean bathrooms and water. Many of our patrons arrive first thing in the morning from a homeless shelter and stay until a shuttle picks them up to take them back in the evening. [112]

The embodied pleasures of reading print books feature prominently in many descriptions of the visceral user in the library.

Commenter 1: I love libraries. No better feel than to just sit in one surrounded by books. 
Commenter 2: Yes, the feel and smell of a book. I'm not one to sit on a phone or iPad and read - haven't understood the whole idea behind that. Convenience, perhaps but the experience of reading a 'book' isn't there. [3]

Even sexual activity may be presented as appropriate for the visceral user, as the emoticons and humorous responses to this disclosure demonstrate:

Commenter 1: I had sex at the [place] library :-)

Commenter 2: I dunno, one of the libraries in [other place] had a few secluded corners. ;-)

Commenter 3: Heh heh... the stacks...

Commenter 4: Yes, I really love checking out the stacked - er, uh, stacks. [55]

In addition to meeting physical needs and desires, the worthy visceral user may engage in activities simply for their pleasurable aspects apart from any need to improve:

Growing up in my hometown back in the day, I spent most of my Saturdays at the library, reading books and looking at magazines .... I checked out books regularly, but just spending the entire weekend just looking magazines of all the pretty things I certainly didn't have at home. It was a nice form of escapism. [55]

know what else saveS folks lives? PLEASURE. There are still people who can't afford tv and streaming services. Maybe grandma just wants to read a juicy romance, maybe your weird uncle on public assistance wants to study ancient gardening techniques. LIBRARIES DO THAT. FOR FREE! [A tweet, reproduced in several items including 11,33 ]

What the library produces is joy. As an English teacher, i have created more joy in the life of cynical students by introducing them to the library, than by confining them to the classroom. Libraries are sacred. [3]

For the worthy visceral user, self-contained physical needs and purely pleasurable activities may appropriately coexist: 
I use my library ... to have a place to hang out on rainy days with kids, to work on my laptop when I need to get out of the house, to look at and post on the community bulletin board, to watch movies on days when school is closed, to attend cheap book sales, for shade and a quick water break on hot sunny afternoons, and for bathroom emergencies when my kids can't hold it downtown. [35]

They are a great place for homeless people to sleep during the day, with bathrooms and water fountains, and if they are literate enough, stuff to read. Also daily papers they can read the comics in and do the crosswords. [100]

However, the visceral user must conform to accepted behavioural norms in order to achieve or maintain worthy user status. While many forms of visceral behaviour, including playing, making noise, eating, drinking, toileting, and engaging in sexual activity, are implicitly or explicitly represented in relation to worthy users, each of these domains may render the user problematic and ill-behaved when it offends other users' sensibilities or interferes with their use of the library.

At one point, Vincent Thomas, the attendant, escorts four grinning teenagers from the building. They seem harmless enough but Vincent darkly mutters about them being 'tried as adults.' What did they do? 'They were messing with the chairs and annoying people,' he says.

The bane of his life, he says, is people eating at the desks. 'A guy had curried chips one day. They're like children taking food out of the bag. They think you can't see them. They're opening the sweets and the paper is crackling.' He sighs. 'You've some right ones.' [131]

Too many patrons think they are in their own living room and do not understand the first tenet of Library Quiet Club: to be quiet.... People just do not have respect anymore is what I have gathered, and library staff are largely apathetic. [101]

In the afternoon I meet someone I knew years ago. He tells me that he now lives in a tent and that the Central Library is one of the first things people tell you about when you become homeless... 'It's warm in winter. You can charge your phone. 
The staff are very nice as long as you don't fall asleep, because it embarrasses them more than anything else.' [131]

No one needs librarians in the age of Google. The money could be better spent hiring security people who could eject foul-smelling 'patrons' more efficiently. [95]

Internet firewalls would be a solid investment too considering the amount of jerking off that takes place. Most of the time it's the homeless so I don't blame them; take it where you can get it. But I think most people would prefer NOT to see homeless dick when searching the stacks for a new cook book... [39]

In this corpus, the behaviour of people whose appearance, sound, or smell deviate from the quiet purpose of the user in-formation is particularly open to scrutiny and judgement.

\section{Discussion}

Considering the representations of users in relation to the categories 'worthy' and 'problem' reveals several interrelated constructions, many of which reflect representations found in scholarly or professional sources. As Barniskis (2016) and Hedemark et al. (2005) found, many descriptions focussed on a fluid 'everyone' as the library's primary responsibility. When the category of 'everyone' was fleshed out, it generally included the 'information poor' (Haider and Bawden, 2007), or what Hedemark et al (2005) call 'neglected groups.' These users were represented as being disadvantaged and in legitimate need of the library's resources, expertise, and support.

A developmental discourse underpins the construction of the user in-formation, who is positioned as deficient or inexperienced and needing to learn from the library programs, resources, or the expert staff (Tuominen, 1997). Children and students are commonly assigned to this category (Lundh, 2016; Rothbauer and Gooden, 2006; 
Stauffer, 2014; Hedemark et al, 2005), as are recent immigrants and language learners. The user in-formation represents both the possibility of worthiness and the risk of problem status. The user in-formation may take proper advantage of the library's offerings and climb the reading ladder (Ross, 1987, 2009; McDowell, 2011, 2014) to achieve success in economic (the library-made user), cultural (the cultured user, Talja, 2001), and civic domains (the informed citizen), or may fail to do so and become a problem: the lazy user, the boor, or the dupe. In relation to the facets of the 'whole user,' (Latham and Lenstra 2018) the user in-formation is primarily understood in occupational and intellectual terms.

Emotional, physical, social, and spiritual dimensions form part of the construction of the visceral user. The worthy, self-contained visceral user who engages in pleasurable activities is reflected in some metaphors of reading identified by Ross (2009). Descriptions of the problematic ill-behaved user reflect prior analyses of children, youth, and some students (e.g., Hedemark et al, 2005; Chelton, 2001; 2002; Bernier, 2011; McDowell, 2011; 2014; Given, 2003).

Figure 1 shows the relationship among the three main categories of users represented in the corpus, with the worthy and problematic variations of the user information and the visceral user.

[Figure 1 near here]

Collectively, the corpus represents worthy library users as exhibiting a particular set of attributes and engaging in a particular set of behaviours that cut across the demographic categories LIS researchers and professionals typically use to describe library users. The visceral user and the user in-formation are distinct but are not, as the diagram suggests, always discrete. Two user demographics, 'the child' and 'the 
homeless person' illustrate how these representations may interrelate.

A category like 'the homeless' may serve as an exemplar of both a worthy member of a neglected group whose presence demonstrates the library's inclusive mandate and reach, and of the problem ill-behaved user whose body is noisy, smells, takes up space, or otherwise comes into conflict with the behavioural norms of other users or of the author of the opinion. This dual presentation echoes Schneider et al's (2011) findings that Canadian newspapers present a unified narrative of homelessness which, on the one hand, exhorts readers to be sympathetic to the plight of homeless people, whilst on the other hand, presents 'them' as needing to be controlled and regulated to maintain social order.

In more general terms, the visceral user is worthy when their behaviour looks like the behaviour of users in-formation

yes, there are numerous vagrants accessing the libraries here. Mostly they use the internet or sit quietly in corners. I don't have a problem with well-behaved homeless people using public services - they're public, that's what public means. [66]

The visceral user becomes a problem when their behaviour impinges on the uses of the user in-formation, as in these examples drawn from discussions of concerns about taking vulnerable children to the library where they might encounter people who represent unpleasant realities of the adult world (Stauffer, 2014). A 'better, family friendly' suburban neighbourhood is a place where such users are discouraged.

In many [U.S. state] cities, libraries have become homeless shelters, and day care for drug/alcohol addicts. The hobos use the bathrooms to clean and bathe...walls and floors decorated with human waste for the poor library janitor to clean up. ... I don't take my kids to our downtown library anymore. [101] 
I have visited our downtown library and even recently there are still cops stationed there kicking out misbehaving individuals. Not sure how much longer that will last. But in reality I mostly go to outlying suburban branches in better, family friendly neighborhoods. [66]

Although children and the adults who bring them to the library are often taken for granted as worthy users in-formation, even they risk losing worthy status if they act in ways consistent with problem visceral users, such as taking up too much space and make too much noise.

Children's storytelling (morning out for mothers) can take place with the mother reading aloud at home. The mothers' cars fill the parking lot at my library. Keep wonderful libraries for books and computer use [71]

Although representations of the visceral user demonstrate popular views of the library serving as more than a place to exercise the mind, commenters privilege behaviour that indicates purposive uses. As Barniskis (2016) observes, 'If the users seek lively, creative, or extemporaneous activity, they may need to go elsewhere. In a mission statement, the phrase "businesslike atmosphere" (especially when paired with the word "respectful") could be code for "shush."

\section{Conclusion}

These representations of users are not surprising; other researchers (and no doubt, readers of this article), have observed them at work in the LIS scholarly and professional literature. What is surprising is to see these familiar representations appearing in descriptions written spontaneously by people who may have no professional connection to libraries, but who nonetheless felt compelled to respond -mostly, but by no means always, in support of public libraries - to a public questioning of library value. 
Moss (2019) argues that it is through representations and stories like these that we make meaning of our world and our place in it. Some stories become dominant, and therefore exert a decisive influence in a particular domain 'by insisting that they are the only way to think, talk and behave, that they are the only reality.... Fictional stories claim to be non-fictional statements: natural, unquestionable, inevitable; excluding or attempting to exclude other ways of understanding and interpreting the world' (pp. 5,6). There is much in common between the ways that contributors to the discussion of public libraries talk about users and what Moss (2019) sees as the dominant discourse in early childhood education, 'the story of quality and high returns,' which sees the education of individuals as the key to the health of the economy as a whole. As Moss explains (p.11), this story begins with a world full of problems, 'including national survival in a fiercely competitive, dog-eat-dog global marketplace and a host of economic and social troubles.' Through the application of the appropriate mix of appropriately-timed individual education and training interventions, 'education and employment outcomes will improve, social problems will diminish, and survival in the "global race", that vortex of ever increasing competition in the global marketplace, will be assured.' Moss locates the origins and hold of this discourse in $20^{\text {th }}$ century neoliberalism with its valuing of competition and choice, the pursuit of individual advantage, and the maximization of efficiency. He argues that neoliberalism has become so pervasive that it is treated as natural and self-evident: every aspect of life is swallowed up by the economic (2019, p.17).

The regularity of the online representations of public library users, and the fact that the stories told in this informal setting align with those told more broadly in LIS, early childhood education, and elsewhere, suggests that they represent a discursive formation. As Radford (2003) explains, Michel Foucault defined the concept of a 
discursive formation as a regularity or order between 'objects, types of statement, concepts, or thematic choices' (Foucault 1972, p.3). Radford (2003) notes that Foucault's scholarship raised 'the discursive formation itself as a legitimate object of inquiry' (p.4, emphasis in original); in other words, 'ma[d]e strange what is familiar' (p.7). The real significance of these representations of library users on the public web is therefore that they are not unique, that they are indicative of ways of thinking about users that are circulating more broadly in the neoliberal environment.

Discursive formations, such as the classification of books into subject categories and their subsequent arrangement on library shelves, have material effects and consequences (Radford 2003, p. 7). The classification a book under Philosophy rather than Art means that the book will be physically shelved with Philosophy titles. The prospective reader is thereby instructed to understand the book in relation to Philosophy literature, and in fact cannot find the book at all without venturing to the Philosophy shelves. The discursive formation of the library classification makes the relationship to Philosophy visible and the relationship to Art invisible. The classification of people similarly has material and potentially devastating effects and consequences as institutionally privileged speakers construct particular identities for groups of people like library users (see, for example, Bowker \& Star, 1998).

Public libraries and other GLAMS (galleries, libraries, archives, and museums) have indeed taken great strides toward broadening collections, programs, and services to meet the emotional, occupational, physical, social, intellectual and spiritual needs of whole user (e.g., Davis, 2019.06.23). Although these public-web representations of library users include representations of the multifaceted whole user, the overarching behavioural norms represented in them prioritize exercising the mind in service of the 
development of the user into a worthy member of a community, and the meeting of behavioural expectations consistent with quiet intellectual activity.

As Hedemark et al (2005) point out, multiple constructions may be at play at a single time; discourses related to what constitutes a worthy user, and correspondingly different understandings of the goals and purposes of the library, conspire and conflict. In a study of public library programmes for young children, McKenzie and Stooke (2012) found that when the goals and purposes of different stakeholders were in sync with one another, they produced positive consequences for staff and users, programmes and services. When library staff and users emphasized different values and goals, they saw different purposes for public library spaces, collections, programs, and services. In some cases the varying purposes were so different that they created negative consequences for individuals and institutions, such as tension or conflict, or the unintentional exclusion of participants from programs designed to be inclusive. McKenzie and Stooke argued that it is crucial to pay attention to the values and purposes emphasized by a variety of participants and stakeholders. If GLAMS privilege the dominant user-in-formation discourse, they risk excluding users whose behaviour may, for good reasons, not align with the expectations for quiet, productive work. At the same time, in an environment where funders of public institutions and the taxpayers who support them are seeking return on public investment, GLAMS ignore the dominant discourse at their peril (e.g., Tremonti, 2019.04.29). Attending to various stakeholders' representations of the values, goals, and purposes of libraries and the characteristics of library users therefore becomes an important strategy, not just for LIS faculty who undertake research in this area, but also for staff whose goal is to serve the whole user and the whole community. 


\section{References}

Barniskis, S. C. (2016). Deconstructing the mission: A critical content analysis of public library mission statements. Library Quarterly, 86(2), pp. 135-152.

Bernier, A. (2011). Representations of youth in local media: Implications for library service. Library \& Information Science Research, 33(2), pp. 158-167.

Black, A. (2005). The library as clinic: A Foucauldian interpretation of British public library attitudes to social and physical disease, ca. 1850-1950. Libraries and the Cultural Record, 40(3), pp. 416-434.

Blessinger, K. D. (2002). Problem patrons: all shapes and sizes. The Reference Librarian, 36(75-76), pp. 3-10. Bowker, G., \& Star, S. L. (1999). Sorting Things Out: Classification and its Consequences. Cambridge, MA: MIT Press

Chattoo, C. D. (2002). The problem patron: Is there one in your library? Reference Librarian, 36(75-76), pp. 11-22.

Chelton, M. K. (2001). Young adults as problems: how the social construction of a marginalized user category occurs. Journal of Education for Library and Information Science, 42(Winter), pp. 4-11.

Chelton, M. K. (2002). The "problem patron" public libraries created. Reference Librarian, 36(75-76), pp. 23-32.

Davis, T. (2019.06.23). Free tampons, pads at some P.E.I. libraries. CBC News, Charlottetown, PE: Canadian Broadcasting Corporation. https://www.cbc.ca/news/canada/prince-edward-island/pei-free-feminiehygiene-kings-1.5186807 Ferrell, S. (2010). Who says there's a problem?: A new way to approach the issue of "problem patrons". Reference and User Services Quarterly, 50(2), pp. 141-151.

Foucault, M. 1972. The Archaeology of Knowledge. Translated by A. M. Sheridan Smith. New York: Pantheon.

Frohmann, B. (1992). The Power of Images: a Discourse Analysis of the Cognitive Viewpoint. Journal of Documentation, 48(4), pp. 365-86.

Given, L. M. (2003). Discursive constructions in the university context: social positioning theory and the mature undergraduates' information behaviours. New Review of Information Behaviour Research, 3(127-142).

Haider, J., \& Bawden, D. (2007). Conceptions of "information poverty" in LIS: A discourse analysis. Journal of Documentation, 63(4), pp. 534-557. 
Hedemark, Å., Hedman, J., \& Sundin, O. (2005). Speaking of users: on user discourses in the field of public libraries. Information Research, 10(2), pp. n.p., paper 218. Retrieved from http://InformationR.net/ir/10-2/paper218.html

Jayyusi, L. (1984). Categorization and the moral order. Boston: Routledge.

Latham, K. F. \& Lenstra, N. (2018) Serving the whole person in GLAMs, Journal of the Australian Library and Information Association, 67(4), 340-342,

Lundh, A. (2016). Subject positions of children in information behaviour research. Information Research, 21(3), n.p.

McDowell, K. (2011). Children's Voices in Librarians' Words, 1890-1930. Libraries \& the Cultural Record, 46(1), pp. 73-101.

McDowell, K. (2014). Open Wide the Doors: The Children's Room as Place in Public Libraries, 1876-1925. Library Trends, 62(3), pp. 519-529.

McKenzie, P. J., \& Stooke, R. K. (2001) Who is entitled to be a literacy expert? Category entitlements of parents and professionals in the literature on children's literacy learning. Beyond The Web: Technologies, Knowledge And People/ AuDelà Du Web: Les Technologies, La Connaissance Et Les Gens. Proceedings of the 29th Annual Conference Of The Canadian Association For Information Science, 27-29 May 2001. http://www.caisacsi.ca/proceedings/2001/McKenzie_2001.pdf

McKenzie, P. J. \& Stooke, R. K. (2012). Making a difference: the importance of purposes to early learning programs. Children and Libraries, Summer/Fall, pp. 47-52.

Moss, P. (2019). Alternative narratives in early childhood: an introduction for students and practitioners. New York: Routledge.

Mourdoukoutas, Panos. 2018a. Amazon Should Replace Local Libraries to Save Taxpayers Money. Forbes. [original version 2018.07.21. Cached: replaced with revised version 2018.07.22] http://archive.is/G1nT7

Mourdoukoutas, Panos. 2018b. Amazon Should Replace Local Libraries to Save Taxpayers Money. Forbes. [revised version 2018.07.22. Cached: removed 2018.07.24] http://archive.is/mPceN

Nardini, R. F. (2001). A search for meaning: American library metaphors, 1876-1926. Library Quarterly, 71(2), pp. 111-140.

Newman, J. (2007). Re-mapping the public. Cultural Studies, 21(6), pp. 887-909. 
Olsson, M. R. (2005). Beyond 'needy' individuals: Conceptualizing information behavior. Proceedings of the American Society for Information Science and Technology, 42(1), $17 \mathrm{pp}$.

Olsson, M. R. (2009/2016). Re-Thinking Our Concept of Users. Australian Academic and Research Libraries, 40(1), pp. 22-35; reprinted in 47(4), pp. 286-299.

Olsson, M. R. (2016). Re-visiting our Concept of Users. Australian Academic and Research Libraries, 47(4), pp. 300-303.

Peatling, G. K. (2002). Historical perspectives on problem patrons from the British public library sector, 1850-1919. Reference Librarian, 36(75-76), pp. 33-43.

Potter, J. (1996). Representing reality: discourse, rhetoric and social construction. Thousand Oaks CA: Sage.

Radford, G. P. 2003. Trapped in our own discursive formations: toward anarchaeology of library and information science. The Library Quarterly, 73(1), pp. 1-18.

Redfern, B. (2002). The difficult library patron: A selective survey of the current literature. Reference Librarian, 36(75-76), pp. 105-113.

Ross, C. S. (1987). Metaphors of reading. Journal of Library history, 22(2), pp. 147163.

Ross, C. S. (2009). Reader on top: Public libraries, pleasure reading, and models of reading. Library Trends, 57(4), pp. 632-656.

Rothbauer, P. M., \& Gooden, R. (2006) Representations of Young People in Information Science: The Case of the Journal of the American Society for Information Science (and Technology), 1985-2005. Paper presented at the Canadian Association for Information Science. http://www.caisacsi.ca/ojs/index.php/cais/article/download/589/256

Schneider, B., Chamberlain, K., \& Hodgetts, D. (2011). Representations of homelessness in four Canadian newspapers: Regulation, control, and social order. Journal of Sociology and Social Welfare, 37(4), pp. 147-172.

Seebruch, N. 2018. Libraries, not just for books anymore. Cornwall seaway news. https://www.cornwallseawaynews.com/news/regional/2018/7/24/libraries--notjust-for-books-anymore.html

Sheih, C. S. M. (2016). An exploratory research on deviant behaviors of problem patrons in Taiwan's public library. Journal of Educational Media and Library Sciences, 53(3), pp. 311-344. 
Shuman, B. A. (1989). Problem patrons in libraries — a review article. Library and Archival Security, 9(2), 3-19.

Stauffer, S. M. (2014). The dangers of unlimited access: Fiction, the Internet and the social construction of childhood. Library \& Information Science Research, 36(34), pp. 154-162.

Stauffer, S. M. (2016). Supplanting the saloon evil and other loafing habits: Utah's library-gymnasium movement, 1907-1912. Library Quarterly, 86(4), pp. 434448.

Talja, S. (2001). Music, Culture, and the Library: An Analysis of Discourses Lanham, MD: Scarecrow Press.

Tremonti, A. M. (2019.04.29). Meals, medical aid and more: The evolving role of public libraries and what they stand to lose. The Current. Toronto: Canadian Broadcasting Corporation. https://www.cbc.ca/radio/thecurrent/the-current-forapril-29-2019-1.5112809/meals-medical-aid-and-more-the-evolving-role-ofpublic-libraries-and-what-they-stand-to-lose-1.5114987

Tuominen, K. (1997). User-Centered Discourse: An Analysis of the Subject Positions of the User and the Librarian. The Library Quarterly, 67(4), pp. 350-371.

Wetherell, M., \& Potter, J. (1988). Discourse analysis and the identification of interpretive repertoires. In C. Antaki (Ed.), Analysing everyday explanation: A casebook of methods (pp. 168-183). Newbury Park, CA: Sage.

Willett, R. (2016). Making, makers, and makerspaces: A discourse analysis of professional journal articles and blog posts about makerspaces in public libraries. The Library Quarterly, 86(3), pp. 313-329.

\section{Appendix 1. Items analysed}

1. Pmourdoukoutas. 2018.07.21. Amazon should replace local libraries to save taxpayers money (original tweet announcing Forbes post, and 210 new conversations in immediate response). Twitter.

https://twitter.com/PMourdoukoutas/status/1020654721655242754

2. Pmourdoukoutas. 2018.07.22. Libraries aren't free. Tweet and conversations in immediate response. https://twitter.com/PMourdoukoutas/status/1021142139823165442 
3. Baker, Deb. 2018.07.22. Really, libraries don't need reinventing, thanks. The

Nocturnal Librarian: musings of a night owl reference librarian.

https://thenocturnallibrarian.com/tag/public-libraries/

4. EveryLibrary. 2018.07.22. Should we replace libraries with Amazon? EveryLibrary's response. https://medium.com/everylibrary/should-we-replace-libraries-with-amazon$\underline{3 \mathrm{f} 67782 \mathrm{dca} 94}$

5. Gilmer, Marcus. 2018.07.22. Flabbergasted Twitter trashes Forbes story that suggests replacing libraries with Amazon. https://mashable.com/2018/07/22/forbes-libraryamazon/\#0QgQAZPHaqqF

6. Gumbinner, Liz. 2018.07.22. Why we need libraries: Twitter claps back against a truly stupid op-ed. https://coolmompicks.com/blog/2018/07/22/why-we-need-librariesforbes-op-ed-turn-libraries-into-bookstores/

7. LibrarianRy. 2018.07.22. Follows of Librarianry tweet in response. https://www.trendsmap.com/twitter/tweet/1020867942467219458

8. McKay, Tom. 2018.07.22. Behold this disastrously bad op-ed calling for Amazon to replace libraries. https://gizmodo.com/behold-this-disastrously-bad-op-ed-calling-foramazon-t-1827789820

9. Meadows, Chris. 2018.07.22. Should we replace public libraries with Amazon books? Not likely! https://teleread.org/2018/07/22/should-we-replace-public-librarieswith-amazon-books-not-likely/

10. Tanzi, Nick. 2018.07.22. Economics Professor Suggests Replacing Libraries with Amazon, is Promptly Destroyed on Twitter. The digital librarian; writing, speaking and consulting with a focus on technology. https://the-digital-

librarian.com/2018/07/22/economics-professor-suggests-replacing-libraries-withamazon-is-promptly-destroyed-on-twitter/ 
11. n.a.2018.07.22. Libraries defended after Forbes article suggests they be replaced by Amazon Books. https://twitter.com/i/moments/1021189116581445632

12. Banks, Marcus. 2018.07.23. On that Forbes library article.

https://medium.com/@marcusbanks/on-that-forbes-library-article-7134e03633bf

13. Becky. 2018.07.23. Suzanne Brockmann 's RWA Lifetime Achievement Speech.

RA for all: training library workers to help leisure readers.

http://raforall.blogspot.com/2018/07/suzanne-brockmann-s-rwa-lifetime.html

14. Cepeda, Cody. 2018.07.23. Professor slammed for saying bookstores should replace libraries. https://usa.inquirer.net/14014/professor-slammed-for-suggesting-librariesshould-be-replaced-by-bookstores

15. Claire. 2018.07.23. In defense of libraries: 4 reasons to love public libraries. clair-efy http://www.clairefyblog.com/2018/07/4-reasons-to-love-the-library.html

16. Closet keys. 2018.07.23. You know that dumbass Forbes article. Tumbler. https://closet-keys.tumblr.com/post/176205363033/you-know-that-dumbass-forbesarticle-advocating?route $=\% 2 \mathrm{Fpost} \% 2 \mathrm{~F} \% 3 \mathrm{Aid} \% 2 \mathrm{~F} \% 3 \mathrm{Asummary}$

17. Cobb, Debbie. 2018.07.23. Things Albany County Public Library does better than Amazon. Laramie Live. http://laramielive.com/things-albany-county-public-librarydoes-better-than-amazon/

18. Cremen, Alanea. 2018.07.23. Forbes op-ed suggests Amazon should take over public libraries; Should Amazon take over public libraries? One op-ed author says yes. https://www.krem.com/article/news/forbes-op-ed-suggests-amazon-should-take-overpublic-libraries/103-576726330

19. Dean, Anthony. 2018.07.23. What digital services do public libraries offer? Diverse tech geek https://www.diversetechgeek.com/2018/07/23/digital$\underline{\text { services-libraries/ }}$ 
20. Gill, Kathy. 2018.07.23. Should Amazon replace public libraries? The moderate voice http://themoderatevoice.com/should-amazon-replace-public-libraries/

21. Grasso, Samantha. 2018.07.23. Libraries should be replaced by Amazon' sets internet ablaze; librarians are ripping this idea to shreds. https://www.dailydot.com/irl/amazon-books-library-forbes-twitter-reactions/ 22. Gutierrez, Lisa. 2018.07.23. Libraries play an important role in our society.' Forbes deletes controversial column. Fort Worth Star-Telegram https://www.kansascity.com/news/nation-world/article215349175.html

23. Ha, Thu-Hong. 2018.07.23. Forbes deleted a deeply misinfomed op-ed arguing Amazon should replace libraries. Quartz. When the Levy Breaks.

https://qz.com/1334123/forbes-deleted-an-op-ed-arguing-that-amazon-should-replace$\underline{\text { libraries/ }}$

24. Herzog, Katie. 2018.07.23. Today in bad ideas: replace libraries with Amazon . https://www.thestranger.com/slog/2018/07/23/29613451/today-in-bad-ideas-replace$\underline{\text { libraries-with-amazon }}$

25. Ingraham, Christopher. 2018.07.23. An awful lot of people use and love their public library, as an economics professor discovered this weekend. Washington Post. https://www.washingtonpost.com/business/2018/07/23/an-awful-lot-people-use-lovetheir-public-library-an-economics-professor-discovered-thisweekend/?noredirect=on\&utm_term $=. e c c 1 b 8 f 8 f 40 \mathrm{c}$ 26. Ivin, Joanna. 2018.07.23. After Forbes Article Claims Libraries Should Be Replaced with Amazon Stores, People Say 'Not So Fast'. C Comic Sands. https://www.comicsands.com/libraries-replaced-by-amazon-stores-2589270377.html 
27. Jensen, Karen. 2018.07.23. Things libraries do that hurt libraries and fail our local communities. School Library Journal http://www.teenlibrariantoolbox.com/2018/07/things-libraries-do-that-hurt-libraries/ 28. Johnson, Stephen. 2018.07.23. Economist causes controversy: 'replace public libraries with Amazon bookstores'. https://bigthink.com/stephen-johnson/controversialforbes-piece-says-us-should-replace-libraries-with-amazon-bookstores 29. Kane, Vivian. 2018.07.23. Forbes got torn apart by library Twitter for saying Amazon should replace public libraries; Alexa, find me the weekend's worst take. The Mary Sue. https://www.themarysue.com/library-twitter-amazon-bad-take/ 30. Klonsky, Fred. 2018.07.23. Replace public libraries with Amazon? Don't tell Rahm. Fred Klonsky. Almost daily posts from a retired public school teacher who is just looking at the data. https://preaprez.wordpress.com/2018/07/23/replace-public$\underline{\text { libraries-with-amazon-dont-tell-rahm/ }}$

31. Lloyd, Sarah Anne. 2018.07.23. Here's what libraries do in Amazon's hometown. Seattle Public Libraries could probably replace Amazon and Starbucks, tbh, not the other way around. https://seattle.curbed.com/2018/7/23/17603536/amazon-librariesseattle-public-library

32. Lyons, Kate. 2018.07.23. Twaddle': librarians respond to suggestion Amazon should replace libraries; Piece in Forbes magazine said libraries 'don't have the same value they used to' and cost taxpayers too much. The Guardian. https://www.theguardian.com/books/2018/jul/23/twaddle-librarians-respond-to$\underline{\text { suggestion-amazon-should-replace-libraries }}$ 33. Marfice, Christina. 2018.07.23. Internet roasts Forbes for saying Amazon can replace libraries. Scarymommy.com. https://www.scarymommy.com/forbes-replacelibraries-amazon/ 
34. Martin, Crystle. 2018.07.23. No, Forbes, libraries cannot be replaced by Amazon. YALSA blog. http://yalsa.ala.org/blog/2018/07/23/no-forbes-libraries-cannot-bereplaced-by-amazon/

35. Martinko, Katherine. 2018.07.23. In defense of libraries -- and why Amazon can never compare. Treehugger. https://www.treehugger.com/culture/defence-libraries-andwhy-amazon-can-never-compare.html 36. n.a.2018.07.23. Librarians are in an uproar after an article in Forbes magazine proposed replacing all public libraries in the US with Amazon bookstores, which said libraries 'don't have the same value they used to' and cost taxpayers too much. https://rebrn.com/re/librarians-are-in-uproar-after-an-article-in-forbes-magazine-pro$\underline{4867862 /}$

37. Nguyen, Jimmy. 2018.07.23. Should Libraries Be Replaced by Amazon Bookstores? Channel 93.3 San Diego's \#1 hit music station. https://channe1933.iheart.com/content/should-libraries-be-replaced-by-amazonbookstores/

38. Orr, Andrew. 2018.07.23. Librarians Respond to Forbes About Amazon Replacing Libraries. https://www.macobserver.com/link/librarians-respond-forbes/ 39. Pat, Gay. 2018.07.23. People are freaking out that a Forbes writer said libraries should be replaced with Amazon bookstores. Barstoolsports.com. https://www.barstoolsports.com/barstoolu/librarians-piledrive-forbes-magazinethrough-a-table-gets-them-to-delete-their-post-saying-amazon-should-replace-libraries/ 40. Peet, Lisa and Kara Yorio. 2018.07.23. Forbes article sparks impassioned defense of libraries. Library Journal. https://www.libraryjournal.com/?detailStory=forbes-articlesparks-impassioned-defense-of-libraries 
41. Perisic, Kyle. 2018.07.23. Librarians push back against call to replace libraries with Amazon. http://dailycaller.com/2018/07/23/librarians-forbes-replace-amazon/

42. Professor rat. 2018.07.23. Forbes article on abolishing libraries https://joindiaspora.com/p/12251186

43. Rarebooksleuth. 2018.07.23. Book news of the day - Economist argues that libraries should be replaced by Amazon bookshops. Librarians respond accordingly. https://steemit.com/books/@ rarebooksleuth/book-news-of-the-day-economist-arguesthat-libraries-should-be-replaced-by-amazon-bookshops-librarians-respond-accordingly 44. Reading, Caleb. 2018.07.23. There's a backlash against the idea to replace libraries with Amazon. https://uproxx.com/viral/forbes-anti-library-op-ed-amazon-backlash/ 45. Robinson, Nathan J. $\quad$ 2018.07.23. Why public libraries are amazing. https://www.currentaffairs.org/2018/07/why-libraries-are-amazing 46. Russo. 2018.07.23. Russo on Empire Falls, Replacing Libraries With Amazon Stores, and More https://www.pw.org/content/russo_on_empire_falls_replacing_libraries_with_amazon_s $\underline{\text { tores_and_more }}$

47. Schaub, Michael. 2018.07.23. Article saying libraries should be replaced by Amazon meets with resounding opposition. LA Times, Books section. http://www.latimes.com/books/la-et-jc-amazon-libraries-20180723-story.html 48. Scott-Hainchek, Sadye. 2018.07.23. Idea of replacing libraries with Amazon stores met with outrage. https://www.thefussylibrarian.com/newswire/2018/07/23/idea-ofreplacing-libraries-with-amazon-stores-met-with-outrage 49. Shelf Awareness. 2018.07.23. Bad idea of the day: 'Amazon should replace local libraries'. http://www.shelf-awareness.com/issue.html?issue=3296\#m41209 
50. Tully, Pat. 2018.07.23. Why I became a librarian. On libraries, history and community. https://ptully01.wordpress.com/

51. Upworthy. 2018.07.23. Replace libraries with Amazon? Not if these librarians have anything to say about it. In case you didn't know, libraries are cool as heck.

https://www.upworthy.com/replace-libraries-with-amazon-not-if-these-librarians-have$\underline{\text { anything-to-say-about-it }}$

52. Vyper, Jake. 2018.07.23. Librarians Furiously Respond To Suggestion That Amazon Should Replace Libraries. http://epicstream.com/news/Librarians-Furiously$\underline{\text { Respond-To-Suggestion-That-Amazon-Should-Replace-Libraries }}$

53. Weissman, Cale Guthrie. 2018.07.23. Forbes deleted its controversial article about Amazon replacing libraries. Fast Company

https://www.fastcompany.com/90206661/forbes-seems-to-have-deleted-its$\underline{\text { controversial-article-about-amazon-replacing-libraries }}$

54. Yorio, Kara. 2018.07.23. Twitter erupts after Forbes story calls for Amazon stores to replace local libraries. School Library Journal.

https://www.slj.com/?detailStory=twitter-erupts-after-forbes-story-calls-for-amazon$\underline{\text { stores-instead-of-local-libraries }}$

55. Zoom, Doktor. 2018.07.23. Forbes Dick Talks Shit About Libraries, Is MURRRRDERED By Vicious Readers Of Books. https://www.wonkette.com/libraries 56. 2018.07.23. Surprisingly, $84 \%$ of US students use libraries these days and this is why. https://typicalstudent.org/hot/news/84-percent-us-students-use-students-uselibraries-these-days-and-this-is-why 57. 2018.07.23. 'Twaddle': librarians respond to suggestion Amazon should replace libraries - Comments. Leadership and Economics. http://leadeconomics.org/blog/2018/07/23/twaddle-librarians-respond-to-suggestion- 
amazon-should-replace-libraries-librarians-are-in-uproar-after-an-article-in-forbesmagazine-proposed-replacing-all-public-libraries-in-the-us-with-amaz/

58. Grothaus, Michael. 2018.07.23.13.23. Forbes suggested Amazon should replace libraries, and people aren't having it. Fast Company.

https://www.fastcompany.com/90206403/forbes-suggested-amazon-shouldreplace-libraries-and-people-arent-having-it 59. 4chan/lit. 2018.07.24. Amazon should replace local libraries to save taxpayers money. http://boards.4chan.org/lit/thread/11500488/amazon-should-replace-locallibraries-to-save 60. Admin. 2018.07.24. The way librarians and Internet respond to Forbes saying we don't need public libraries is going viral. https://fdmania.com/the-way-librarians-andinternet-respond-to-forbes-saying-we-dont-need-public-libraries-is-going-viral/ 61. Amanda. 2018.07.24. A new form of Amazon Derangement Syndrome. https://madgeniusclub.com/2018/07/24/a-new-form-of-amazon-derangement-syndrome/ 62. berryvillelibrary. 2018.07.24. In defense of local libraries. Berryville Book Buzz; Growing a bigger, better library. https://berryvillebookbuzz.wordpress.com/ 63. Clark, Nicole. 2018.07.24. No, Amazon Cannot Replace Libraries; Libraries are essential to our communities, in ways that even frequent patrons might not know. https://www.vice.com/en_us/article/mb4b98/no-amazon-cannot-replace-libraries 64. College Fix Staff. 2018.07.24. Forbes deletes article from economics professor calling for Amazon to replace libraries. https://www.thecollegefix.com/post/47153/ 65. Cross, Ian. 2018.07.24. 5 things you probably didn't know your local library provides. https://www.news5cleveland.com/news/local-news/5-things-you-probablydidnt-know-your-local-library-provides 
66. Elspeth. 2018.07.24. Forbes pulls stupid article which suggested that Amazon could replace public libraries. Reading in between the life... because life is where the real learning takes place. https://terrysbookobsession.wordpress.com/2018/07/24/forbespulls-stupid-article-which-suggested-that-amazon-could-replace-public-libraries/ 67. Eyre, Charlotte. 2018.07.24. Forbes removes article suggesting Amazon should replace libraries. The bookseller. https://www.thebookseller.com/news/forbes-removes$\underline{\text { article-suggesting-amazon-should-replace-libraries-835571 }}$

68. Faraudo, Franco. 2018.07.24. Forbes article critical of public libraries faces backlash. https://propmodo.com/forbes-article-critical-of-public-libraries-faces$\underline{\text { backlash/ }}$

69. Grady, Constance. 2018.07.24. Why public libraries are still essential in 2018. Vox. https://www.vox.com/culture/2018/7/24/17603692/public-libraries-essential-forbes$\underline{\text { amazon }}$ 70. Illichmann, Christine. 2018.07.24. SIS alumna responds to Forbes article with a dose of reality. Ideas from SIS at Wayne State University. https://blogs.wayne.edu/sis/sis-alumna-responds-to-forbes-article-with-a-dose-ofreality/

71. Jaschik, Scott. 2018.07.24. Forbes, attacked by librarians, yanks essay. Inside Higher Ed. https://www.insidehighered.com/quicktakes/2018/07/24/forbes-attackedlibrarians-yanks-essay

72. Johnson, Cyree Jarelle. 2018.07.24. Turning libraries in to Amazon stores is class warfare: public libraries incubate working-class brilliance, and privatizing them would be a terrible injustice. https://motherboard.vice.com/en_us/article/ne57jz/replacing$\underline{\text { libraries-with-amazon-forbes-article }}$ 
73. Lane, Hilary. 2018.07.24. Local outrage after Forbes article says Amazon Bookstores should replace libraries; While the author of the Forbes article argued that libraries are obsolete, data from the DC library system tells a different story. WUSA 9. https://www.wusa9.com/article/money/consumer/local-outrage-after-forbes-articlesays-amazon-bookstores-should-replace-libraries/65-577081609

74. Lutkin, Aimee. 2018.07.24. People Are Remembering Prince After Someone Suggested Closing Public Libraries. https://www.distractify.com/trending/2018/07/23/X97ne/prince-loved-libraries 75. McBee, Josh. 2018.07.24. As Forbes author slams libraries, Metro system breaks records. https://nondoc.com/2018/07/24/forbes-author-slams-libraries/ 76. McMurtrie, John. 2018.07.24. A look at some of the world's most beautiful libraries. https://www.sfchronicle.com/books/article/A-look-at-some-of-the-world-s-mostbeautiful-13101635.php

77. n.a.2018.07.24. Forbes deletes op-ed arguing Amazon should replace libraries; an economist said it would "save taxpayers money" http://www.realclearlife.com/dailybrief/forbes-deletes-op-ed-arguing-amazon-replace-libraries/

78. n.a.2018.07.24. Forbes removes article saying libraries should be replaced by Amazon. KTLA 5. https://ktla.com/2018/07/24/forbes-removes-article-saying-librariesshould-be-replaced-by-amazon/

79. n.a. 2018.07.24. Should Amazon bookstores replace LI public libraries? Newsday. https://www.newsday.com/long-island/library-amazon-book-stores-1.20061196 80. Nefas, Ligitas. 2018.07.24. Forbes Suggests Replacing Libraries With Amazon Stores, Librarians and Internet Respond in Best Way. https://www.boredpanda.com/forbes-suggestion-amazon-replace-librariesreactions/ 
81. Nickelsburg, Monica. 2018.07.24. Why Forbes took down that controversial op-ed calling for Amazon to replace public libraries. https://www.geekwire.com/2018/forbes$\underline{\text { took-controversial-op-ed-calling-amazon-replace-public-libraries/ }}$

82. Nolos, Alex. 2018.07.24. Forbes Removes Article Calling for Libraries to Shut Down in Favor of Amazon; Libraries are more than just buildings with books. Book culture. https://www.bookstr.com/libraries-will-win-every-time

83. Peaadmin. 2018.07.24. The furor over Forbes; or why Amazon should not replace libraries. http://www.peabodylibrary.org/freeforall/?p=10061

84. Rarebooksleuth. 2018.07.24. Book news of the day (Updates from yesterday's post) - Forbes deletes Op-Ed arguing libraries should be replaced by Amazon bookstores. https://steemit.com/books/@rarebooksleuth/book-news-of-the-day-update-fromyesterday-s-post-forbes-deletes-op-ed-arguing-libraries-should-be-replaced-by-amazon$\underline{\text { bookstores }}$

85. Rowles, Dustin. 2018.07.24. Forbes pulls anti-library article after social media goes Apesh*t. Pajiba. http://www.pajiba.com/miscellaneous/forbes-pulls-antilibrary$\underline{\text { article-after-social-media-goes-apesht.php }}$

86. Ryan, Shane. 2018.07.24. With this Idiotic "Essay" on Amazon and Public Libraries, We have Reached Peak Capitalism. https://www.pastemagazine.com/articles/2018/07/with-this-idiotic-essay-on-amazonand-public-libra.html

87. Schneider. 2018.07.24. LIU Post professor's anti-library Op-Ed stirs strong outcry; Economics professor Panos Mourdoukoutas's opinion piece in Forbes magazine says libraries are outdated but supporters see them as playing a vital community role. Newsday. https://www.newsday.com/long-island/amazon-libraries-professor$\underline{1.20075966}$ 
88. Simmons, Scott. 2018.07.24. Libraries still busy, popular contrary to Forbes column's claim. 'Anti-library' column deleted. http://www.wapt.com/article/libraries$\underline{\text { still-busy-popular-contrary-to-forbes-columns-claim/22538379 }}$

89. Sims, Emma. 2018.07.24. Why Amazon will never replace libraries.

http://www.alphr.com/life-culture/1009751/why-amazon-will-never-replace-libraries 90. Tempesta, Erica. 2018.07.24. Twitter users furiously fire back. Daily Mail. http://www.dailymail.co.uk/femail/article-5984085/Twitter-users-fire-economists-oped-argues-libraries-replaced-AMAZON.html

91. Bussel, Rachel Kramer. 2018.07.24. Why a (now-deleted) op-ed about replacing libraries with Amazon blew up the internet. CNN Opinion -- political op-eds commentary. https://www.cnn.com/2018/07/23/opinions/forbes-amazon-librarieswrong-for-many-reasons-kramer-bussel-opinion/index.html 92. Annear, Steve. 2018.07.25. The Somerville Public Library had a stuffed animal sleepover, and it was adorable. Boston Globe. https://www.bostonglobe.com/metro/2018/07/25/the-somerville-public-library-hadstuffed-animal-sleepover-and-was-adorable/MPt47adwIeEpPLZDvXCpTO/story.html 93. Barchas-Lichtenstein, Jena, Rebecca Joy Norlander, and Deb Robertson. 2018.07.25. Libraries are about much more than books -- and they always have been. newknowlege.org: facing society's challenges head on.

https://www.newknowledge.org/culture/libraries-are-about-much-more-than-books-andthey-always-have-been/

94. Cabrera, Justin. 2018.07.25. Librarians destroy Forbes writer who wants to replace libraries with Amazon bookstores. https://en.softonic.com/articles/librarians-destroy$\underline{\text { forbes-writer-who-wants-to-replace-libraries-with-amazon-bookstores }}$ 
95. Ciccotta, Tom. 2018.07.25. Forbes deletes article on replacing libraries with Amazon. [With comments]. https://www.breitbart.com/tech/2018/07/25/forbesdeletes-article-on-replacing-libraries-with-amazon/

96. Credeur, Aaron. 2018.07.25. Fact or fiction: is replacing public libraries with Amazon Bookstores a smart investment? https://ijr.com/2018/07/1111448-amazonlibrary-fact-check/

97. Editorial. 2018.07.25. Stand up for libraries. Hi-desert star. http://www.hidesertstar.com/opinion/editorials/article_f855c604-9067-11e8-895d$\underline{\text { 1bd60d3ea738.html }}$

98. Hyde, Justine. 2018.07.25. For the love of libraries. Meanjin Quarterly. https://meanjin.com.au/blog/for-the-love-of-libraries/ 99. Ibbetson, Connor. 2018.07.25. Could Amazon actually replace all US libraries? https://media.thinknum.com/articles/could-amazon-actually-replace-all-us-libraries/ 100. Msmash. 2018.07.25. No, Amazon cannot replace libraries. [post with 200+ comments] https://news.slashdot.org/story/18/07/25/1759213/no-amazon-cannot$\underline{\text { replace-libraries }}$ 101. Passy, Jacob. 2018.07.25. Why libraries are an economic lifeline for millions of Americans; some social commentators say corporations should replace these public institutions. https://www.marketwatch.com/story/libraries-are-an-economic-lifeline-formillions-of-americans-2018-07-24

102. San Juan, Diana. 2018.07.25. San Francisco Public Library responds after Forbes Op-Ed suggests Amazon should replace public libraries. "Maybe Forbes doesn't like that you can download their magazine free with your \#SF library card," the SF Public Library tweeted. https://www.nbcbayarea.com/news/local/Forbes-Op-ed-SuggestAmazon-Should-Replace-Libraries-SF-Public-Library-Responds-489152641.html 
103. 2018.07.25. LIU Post professor: Amazon should replace local libraries.

http://bronx.news12.com/story/38730585/liu-post-professor-amazon-should-replacelocal-libraries

104. 2018.07.25. 'Forbes' pulls opinion piece arguing Amazon should replace libraries after public backlash.

https://www.booksandpublishing.com.au/articles/2018/07/25/111993/forbes-pullsopinion-piece-arguing-amazon-should-replace-libraries-after-public-backlash/

105. Cline, Kimberley. 2018.07.26. Long Island University.

https://headlines.liu.edu/?p=2051

106. DeMont, John. 2018.07.26. The golden age of the library. Halifax Chronicle-

Herald. http://thechronicleherald.ca/opinion/1586533-demont-the-golden-age-of-thelibrary

107. Fleming, Lindsey. 2018.07.26. Libraries offer so much more than books.

Dominion Post. https://www.dominionpost.com/2018/07/26/libraries-offer-so-much$\underline{\text { more-than-books/ }}$

108. Garcia, Corey. 2018.07.26. In addition to libraries, let's rally around public gyms too. Houston Press. https://www.houstonpress.com/arts/the-case-for-more-publicindoor-gyms-10694482

109. Garcia-Febo, Loida. 2018.07.26. Libraries are better stewards of taxpayer dollars than corporations. Publisher's Weekly.https://www.publishersweekly.com/pw/bytopic/columns-and-blogs/editorials/article/77590-libraries-are-better-stewards-oftaxpayer-dollars-than-corporations.html 110. Kennerly, Britt. 2018.07.26. Let's close book on absurd idea to shutter public libraries. Florida Today (part of USA Today network). 
https://www.floridatoday.com/story/news/2018/07/26/lets-close-book-absurd-ideashutter-public-libraries/834402002/

111. Midpointe Library. 2018.07.26. Libraries replaced by Amazon? We think not. The Pointe: Midpointe Library's Official Blog.

https://www.midpointelibraryblog.org/blog/2018/7/26/libraries-replaced-by-amazonwe-think-not

112. Oliver, Amanda. 2018.07.26. I'm a librarian. The last thing we need is Silicon Valley "disruption." A Forbes column arguing that Amazon should replace libraries grossly underestimates how many services libraries offer. https://www.vox.com/firstperson/2018/7/26/17616516/amazon-silicon-valley-libraries-forbes

113. Seidlinger, Michael. 2018.07.26. A Forbes contributor has suggested replacing libraries with Amazon bookstores. https://www.mhpbooks.com/a-forbes-contributor$\underline{\text { has-suggested-replacing-libraries-with-amazon-bookstores/ }}$

114. Star-Herald Opinion. 2018.07.26. Editorial: Libraries are a good investment. Scottsbluff Star-Herald. https://www.starherald.com/opinion/editorial-libraries-are-agood-investment/article_ffaab0f3-d578-55fa-9dfe-9bea7763badb.html 115. Tolbert, Autumn. 2018.07.26. Loving libraries. Ark Times. https://www.arktimes.com/arkansas/loving-libraries/Content?oid=20733114 116. Zalusky, Steve. 2018.07.26. Forbes opinion piece stirs outrage among library advocates. Ilovelibraries.org (an initiative of the American Library Association). http://ilovelibraries.org/article/forbes-opinion-piece-stirs-outrage-among-library$\underline{\text { advocates }}$ 117. 2018.07.26. UCSD's Geisel Library named one of the most beautiful libraries in the world. CBS News 8 San Diego. http://www.cbs8.com/story/38746082/ucsds-geisellibrary-named-one-of-the-most-beautiful-libraries-in-the-world 
118. Albanese, Andrew. 2018.07.27. This week in libraries: July 27, 2018. Publisher's Weekly. https://www.publishersweekly.com/pw/by-topic/industrynews/libraries/article/77609-the-week-in-libraries-july-27-2018.html 119. Anglin, Maria. 2018.07.27. No, Amazon cannot replace libraries. My San Antonio. https://www.mysanantonio.com/opinion/columnists/maria_anglin/article/No-Amazoncannot-replace-libraries-13111737.php

120. Brasher, Justin. 2018.07.27. Amazon replacing libraries? Not on our watch. https://brashlibrarian.com/2018/07/27/amazon-replacing-libraries-not-on-our-watch/ 121. Carleton Place Public Library. 2018.07.27. Libraries replaced by Amazon?

Absurd! $\quad$ Tales from an open book; the Carleton Place Public Library Blog. https://talesfromanopenbook.wordpress.com/ 122. Gardner, James Alan. 2018.07.27. Sharing: July 25, 2018. https://jamesalangardner.wordpress.com/ 123. Kate. 2018.07.27. Why we love libraries (it's not just about the books!) On our way world. We are a family of four pursuing financial freedom.... https://onourwayworld.com/2018/07/27/why-we-love-libraries-its-not-just-about-the$\underline{\text { books/ }}$

124. Nelson, Rick. 2018.07.27. Libraries not in need of Silicon Valley disruption, librarian says. Evaluation engineering; written by engineers... for engineers. https://www.evaluationengineering.com/libraries-not-in-need-of-silicon-valleydisruption-librarian-says 125. Phillips, Gary. 2018.07.27. Letter: our libraries are worth it Letters to the editor: Northwest Herald. http://www.nwherald.com/2018/07/27/letter-our-libraries-are-worth$\underline{\mathrm{it} / \mathrm{ah} 0080 \mathrm{~h} /}$ 
126. Phillipson, Daisy. 2018.07.27. Why libraries are an important resource for indie filmmakers. Film Daily. https://filmdaily.co/news/why-libraries-are-an-important$\underline{\text { resource-for-indie-filmmakers/ }}$

127. Trueman, Charlotte. 2018.07.27. News roundup: Facebook takes a major financial hit. A roundup of the week' s technology news. https://www.idgconnect.com/blog$\underline{\text { abstract/31126/news-roundup-facebook-takes-major-financial-hit }}$ 128. WhatTheyThink staff. 2018.07.27. Around the Web: Amazon to Replace Libraries? - Book Fore-Edge Painting - The Truth About Recycled Clothing - Japan's Looming "Y2K"-Like Problem - This Week in Printing History http://whattheythink.com/articles/91004-around-web-amazon-replace-libraries-bookfore-edge-painting-truth-about-recycled-clothing-japans-looming-y2k-problem-weekprinting-history/

129. 2018.07.27. Bronx libraries get funding for infrastructure, technology upgrades http://longisland.news12.com/story/38754087/bronx-libraries-get-fundin 130. Etzler, Allen. 2018.07.28. Frederick County libraries continue to evolve in digital age.

https://www.fredericknewspost.com/news/politics_and_government/levels_of_governm

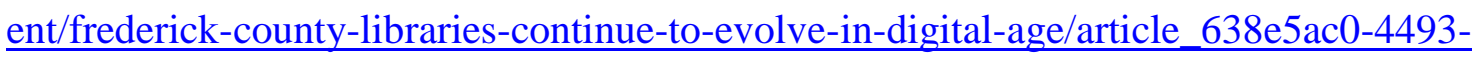
$\underline{\text { 5ae9-8960-33368d4b7ff2.html }}$

131. Freyne, Patrick. 2018.07.28. A day in the library: 'This is a safe space for people'. In other countries libraries may be under threat but there's a queue every morning outside Dublin's Central Library. Irish Times https://www.irishtimes.com/culture/books/a-day-in-the-library-this-is-a-safe-space-forpeople-1.3578203 
132. Strauss Consultants. 2018.07. Amazon should not take over libraries.

http://straussconsultants.com/amazon-should-not-take-over-libraries/

133. Reddit. San Francisco. n.d. Forbes article suggests that Amazon should replace public libraries. SF Public Library responded. sanfrancisco.

https://www.reddit.com/r/sanfrancisco/comments/918pfg/forbes_article_suggests_that amazon_should/

134. Reddit. Libraries. n.d. Forbes article: replace libraries with Amazon stores.

Forums.

https://www.reddit.com/r/Libraries/comments/90zqeh/forbes_article_replace_libraries_ with_amazon/

135. Deruyter. n.d. Thread: Uproar: Forbes magazine proposed replacing public libraries with Amazon bookstores. https://www.mmo-champion.com/threads/2414035Uproar-Forbes-magazine-proposed-replacing-public-libraries-with-Amazon-bookstores 136. Andrews, Mark. n.d. "Amazon should replace libraries," says Forbes writer and it sparks debate online. According to writer, doing so would help "save taxpayers money." https://www.elitereaders.net/amazon-should-replace-libraries/ 137. Donnelly, Brenna. n.d. Brownsburg councilor, community react to viral library idea. https://www.wishtv.com/news/local-news/brownsburg-councilor-community$\underline{\text { react-to-viral-library-idea/1326341014 }}$ 138. SBG San Antonio. n.d. Twitter argument fuels idea of Amazon bookstores replacing public libraries. https://foxsanantonio.com/news/local/twitter-argument-fuels$\underline{\text { idea-of-amazon-bookstores-replacing-public-libraries }}$ 139. Cheshire Public Library. n.d. I'm a librarian. Amazon could never replace what I do. Cheshire Public Library Tumblr. http://cheshirelibrary.tumblr.com/ 
140. Democratic Underground. n.d. "Twaddle' librarians respond to suggestion Amazon should replace libraries comments- Democratic Underground.

https://upload.democraticunderground.com/100210913664 